\title{
RELATIONSHIP OF LEARNING INDEPENDENCE, PARENTING AND LEARNING ENVIRONMENT IN SCHOOLS WITH RESULTS OF MATHEMATICS STUDENTS IN SMP N 15 YOGYAKARTA
}

\author{
Rizka Nurcahyatia ${ }^{\mathrm{a}}$, Suparyan ${ }^{\mathrm{b}}$ \\ Program Studi Pendidikan Matematika Universitas Ahmad Dahlan \\ Jalan Ring Road Selatan, Tamanan, Banguntapan, Bantul Yogyakarta \\ achikaramlan@gmail.com, ${ }^{\text {bsuparyan.uad@gmail.co.id }}$
}

\begin{abstract}
Low student learning outcomes are related to many factors. Learning Independence, Parenting Parents and the Learning Environment in Schools are several factors that are thought to be related to learning outcomes. This study aims to determine whether or not there is a positive and significant relationship between learning independence, parenting parents and the learning environment in schools with mathematics learning outcomes for students of class VIII SMP N 15 Yogyakarta odd semester 2016/2017 academic year. The population in this study were eighth-grade students of SMP N 15 Yogyakarta in the 2016/2017 school year, consisting of classes VIII F, VIII G, VIII H, VIII I, VIII J, with a total of 167 students. Samples were taken from class VIII H as a class of research samples with random sampling techniques to the class .. Data collection techniques using questionnaires to obtain data on learning independence, parenting parents and learning environment at school, as well as test methods to obtain data on mathematics learning outcomes. Research instrument test: validity test, different power test, and reliability test. Analysis prerequisite tests include normality test, linearity test, and independence test. Data analysis uses product moment analysis and multiple linear regression analysis. The results showed that there was a positive and significant relationship between learning independence, parenting parents, and the learning environment at school with mathematics learning outcomes for students of class VIII SMP N 15 Yogyakarta Odd Semester 2016/2017 Academic Year. This is indicated by Fcount $>$ $\mathrm{F}_{\text {table }}$ is $451.4123>2.9223$ with $\mathrm{R}=0.9891$ and $\mathrm{R}^{2}=0.9783$ with $\widehat{Y}=-190.9314+2.1190 X_{1}-$ $0.7093 X_{2}+1.5212 X_{3}$, with SR $\mathrm{X}_{1}=39.0475 \%, \mathrm{SR} \mathrm{X}_{2}=13.1216 \%$ and $\mathrm{SR} \mathrm{X}_{3}=47.8309 \%$, SE $\mathrm{X}_{1}=38.2013 \%, \mathrm{SE} \mathrm{X}_{2}=12.8372 \%$ and $\mathrm{SE} \mathrm{X}_{3}=46.7943 \%$.
\end{abstract}

Keywords: Independence Learning, Parenting, and Learning Environment in School, Mathematics Learning Outcomes.

\section{INTRODUCTION}

Education plays an important role to ensure the survival of a nation and state, and to develop the quality of human resources. The realization of quality society is the responsibility of education, especially in preparing students to become objects that increasingly play a role in displaying their creative, independent, and professional excellence in their respective fields. Various attempts were made by someone to get an education. With education, someone will get knowledge. With human science will develop towards maturity. Mathematics is called the queen of knowledge. So, mathematics is the main key to other knowledge learned in school. The purpose of mathematics education at primary and secondary education levels is to emphasize the structuring of reasoning and the formation of personality (attitudes) of students so that they can apply or use mathematics in their lives. Thus mathematics becomes a very important subject in education and must be studied at every level of education. Each individual has a different view of mathematics. There are those who view mathematics as a pleasant subject and there are also those who view mathematics as a difficult subject. For those who think mathematics is fun, it will grow motivation in these individuals to learn mathematics and be optimistic in solving problems that are challenging in mathematics. Conversely, for those who consider mathematics as a difficult subject, the individual will be pessimistic in solving mathematical problems and less motivated to learn them. These attitudes will certainly affect the results they will achieve in learning.

According to Slameto (2013: 54), "Factors that influence learning of many types, but can be classified into two groups, namely internal factors, and external factors." Internal factors are factors that originate from within students, including attention, interest, talent, intelligence, discipline, independence, motivation, self-confidence and others. External factors are factors that come from outside the student, 
including family, environment, school, community, facilities and infrastructure, weather, and others. Independence is one example of internal factors. Learning independence is very necessary in learning mathematics because, in the teaching and learning process, students who have learning independence tend to be calm when facing a problem working on learning tasks because they have high self-confidence so that they are not easily influenced by the opinions of others. An external factor that has a role in the learning process of students is parenting. Parents are the first and foremost educators for their children. Parenting patterns play an important role in the development of children's learning and a very large effect on the level of achievement of children's learning outcomes in school. Another external factor is the learning environment at school. Supporting the success of the teaching and learning process in schools cannot be separated from the role of the teacher, students, infrastructure, and the school itself. A healthy and pleasant learning environment at school allows students to have good social interactions so as to arouse student learning.

The problems in this study are: 1) Is there a positive and significant relationship between learning independence and mathematics learning outcomes of students of class VIII SMP N 15 Yogyakarta odd semester 2016/2017 academic year? 2) Is there a positive and significant relationship between parenting parents with the mathematics learning outcomes of students of class VIII SMP N 15 Yogyakarta odd semester 2016/2017 school year ?, 3) Is there a positive and significant relationship between the learning environment at school with the mathematics learning outcomes of students of class VIII SMP N 15 Yogyakarta odd semester 2016 school year / 2017 ?, 4) Is there a positive and significant relationship between learning independence and parenting parents with mathematics learning outcomes for students of class VIII SMP N 15 Yogyakarta odd semester 2016/2017? 5) Is there a positive and significant relationship between learning independence and learning environment in schools with mathematics learning outcomes for students of class VIII SMP N 15 Yogyakarta odd year semester 2016/2017 teaching ?, 6) Is there a positive and significant relationship between parenting and learning environment in schools with mathematics learning outcomes for students of class VIII SMP N 15 Yogyakarta odd semester 2016/2017? 7) Is there a positive relationship and significant between the independence of learning, parenting parents, and the learning environment in schools with mathematics learning outcomes of students of class VIII SMP N 15 Yogyakarta odd semester 2016/2017 school year.

The purpose of this study are: 1) To find out whether or not there is a positive and significant relationship between learning independence and mathematics learning outcomes of eighth grade students of SMP N 15 Yogyakarta odd semester 2016/2017 academic year, 2) To find out whether or not there is a relationship that is positive and significant relationship between parenting and mathematics learning outcomes of class VIII students of SMP N 15 Yogyakarta odd semester 2016/2017 academic year 3) To find out whether there is a positive or significant relationship between the learning environment at school and mathematics learning outcomes Grade VIII students of SMP N 15 Yogyakarta odd semester 2016/2017 academic year, 4) To find out whether or not there is a positive and significant relationship between learning independence and parenting parents with mathematics learning outcomes of VIII grade students of SMP N 15 Yogyakarta in odd semester 2016/2017 teaching, 5) To find out whether or not there is a positive and significant relationship fiction between learning independence and the learning environment at school with mathematics learning outcomes for students of class VIII SMP N 15 Yogyakarta odd semester 2016/2017,6) To find out whether or not there is a positive and significant relationship between parenting patterns and the learning environment at school with mathematics learning outcomes for students of class VIII SMP N 15 Yogyakarta odd semester 2016/2017 academic year 7) To find out whether or not there is a positive and significant relationship between learning independence, parenting patterns and the learning environment at school with mathematics learning outcomes Grade VIII students of SMP N 15 Yogyakarta odd semester 2016/2017 academic year.

\section{THEORY}

The concept that is often used or close to independence is autonomy. According to Chaplin in Desmita (2009: 185) autonomy is the freedom of individual human beings to choose, to become a unit that 
can govern, control and determine themselves. Whereas Seifert and Hoffnung in Desmita (2009: 185) defines autonomy or independence as the ability to govern and regulate one's own thoughts, feelings, and actions freely and responsibly while overcoming feelings of shame and doubt. According to Djamarah, Syaiful Bahri (2014: 50) parenting in the family is a phrase that collects four important elements, namely patterns, foster care, parents, and family. Meanwhile, according to Tafsir, Ahmad in Djamarah, Syaiful Bahri (2014: 51) parenting means education. Thus, parenting is a parental effort that is consistent and persistent in looking after and guiding children from birth to adolescence. According to Sartain, quoted by Purwanto, N (2014: 28), Environment includes all conditions in this world which in certain ways affect our behavior, growth, development, or life processes except for genes and even genes. genes are seen as preparing the environment for other genes. According to Djamarah, Syaiful Bahri (2011: 180-185) in determining the direction and objectives, a set of completeness in various forms and types is needed, namely curriculum, programs, facilities and facilities, and teachers.

\section{METHODS}

The type of this research is the type of non-experimental research and quantitative research using correlation research. In this study using one class, the sample class. The population in this study were students of class VIII F, VIII G, VIII H, VIII I, and VIII J SMP N 15 Yogyakarta in the 2016/2017 school year so that they consisted of only 5 classes totaling 167 students. While the sample in this study was class VIII H. The sampling technique used was Random Sampling of the class. Data collection techniques used were questionnaire techniques with instruments in the form of questionnaires and test techniques in the form of objective questions in the form of multiple choice. The analysis prerequisite test is the normality test with the Chi-squared formula, the linearity test of the F-test formula and the Chi-squared formula independence test. Research hypothesis testing uses a simple correlation test, multiple regression analysis test and multiple linear regression test with three independent variables. Research hypothesis testing using a simple correlation test is performed to determine the presence or absence of positive and significant relationships between 1) learning independence with student mathematics learning outcomes, 2) parenting parents with student mathematics learning outcomes, 3) learning environment in schools with student learning outcomes in mathematics. Furthermore, the research hypothesis test uses a multiple regression analysis tests conducted to determine the presence or absence of a positive and significant relationship between 1) learning independence and old parenting with student mathematics learning outcomes, 2) learning independence and learning environment in schools with mathematics learning outcomes students, 3) parenting and learning environment in schools with student mathematics learning outcomes. Whereas the multiple linear regression test with three independent variables was carried out to determine the presence or absence of a positive and significant relationship between learning independence, parenting parents and the learning environment at school with student mathematics learning outcomes.

\section{RESULTS}

\section{Test Prerequisite Regression Analysis}

\section{A. Normality Test}

The summary of normality test results can be seen in Table 1 .

Table 1. Summary of Normality Test Results

\begin{tabular}{|l|l|l|l|}
\hline Variable & $\boldsymbol{\chi}_{\text {count }}^{\mathbf{2}}$ & $\mathbf{d f}$ & $\boldsymbol{\chi}_{\text {table }}^{\mathbf{2}}$ \\
\hline $\mathrm{X}_{1}$ & 2,7915 & 2 & 5,9915 \\
\hline $\mathrm{X}_{2}$ & 3,0474 & 2 & 5,9915 \\
\hline $\mathrm{X}_{3}$ & 1,5609 & 3 & 7,8147 \\
\hline $\mathrm{Y}$ & 2,2626 & 3 & 7,8147 \\
\hline
\end{tabular}

From the normality test at a significant level of $5 \%$ seen $\chi_{\text {count }}^{2} \leq \chi_{\text {table }}^{2}$, this means that the distribution of data obtained in each variable is normally distributed. 


\section{B. Linearity Test}

The summary of linearity test results can be seen in Table 2 .

Table 2. Summary of Linearity Test Results

\begin{tabular}{|c|c|c|}
\hline Variable & $\mathbf{F}_{\text {count }}$ & $\mathbf{F}_{\text {table }}$ \\
\hline $\mathrm{X}_{1}$ and $\mathrm{Y}$ & 1,1315 & 2,3683 \\
\hline $\mathrm{X}_{2}$ and $\mathrm{Y}$ & 0,8523 & 2,4709 \\
\hline $\mathrm{X}_{3}$ and $\mathrm{Y}$ & 0,3245 & 2,7541 \\
\hline
\end{tabular}

From the linearity test at a significant level of $5 \%(\alpha=0.05)$ and degrees of freedom $\mathrm{v}_{1}$ numerator $=\mathrm{k}-2$ and $\mathrm{v}_{2}$ the denominator $=\mathrm{n}-\mathrm{k}$ is seen $F_{\text {count }} \leq F_{\text {table }}$, with $F_{\text {table }}=((1-\alpha)(\mathrm{k}-2, \mathrm{~N}-\mathrm{k}))$, this means that there is a linear relationship between the independent variable $(\mathrm{X})$ and the dependent variable $(\mathrm{Y})$.

C. Independence Test

The summary of independence test results can be seen in Table 3 .

Table 3. Summary of Independence Test Results

\begin{tabular}{|l|l|l|}
\hline Variable & $\boldsymbol{\chi}_{\text {count }}^{\mathbf{2}}$ & $\boldsymbol{\chi}_{\text {table }}^{\mathbf{2}}$ \\
\hline$X_{1}$ and $X_{2}$ & 31,856 & 37,652 \\
\hline$X_{1}$ and $X_{3}$ & 32,917 & 37,652 \\
\hline$X_{2}$ and $X_{3}$ & 24,682 & 37,652 \\
\hline
\end{tabular}

From the independence test at a significant level of $5 \%(\alpha=0.05)$ and degrees of freedom $(\mathrm{df})=$ $\mathrm{k}-1)$ (b-1) seen $\mathrm{X}_{\text {count }}^{2} \leq X^{2}$ table, this means that the distribution of data obtained on each variable are mutually independent.

\section{Hypothesis testing}

The summary of the results of the first hypothesis test can be seen in Table 4 .

Table 4. Summary of First Hypothesis Test Results

\begin{tabular}{|c|c|c|c|}
\hline $\boldsymbol{t}_{\text {count }}$ & $\boldsymbol{t}_{\text {table }}$ & $\mathbf{d f}$ & Info \\
\hline 2,4726 & 2,0395 & 32 & $\begin{array}{l}\mathrm{H}_{0} \text { is rejected, } \\
\mathrm{H}_{1} \text { is accepted }\end{array}$ \\
\hline
\end{tabular}

From the first hypothesis test at a significant level of $5 \%$ and $\mathrm{df}=32$, it can be seen that $\mathrm{t}_{\text {count }}=2.4726$ and $t_{\text {table }}=2.0369$ so $t_{\text {count }}>t_{\text {table }}$ This means that there is a positive and significant relationship between learning independence and mathematics learning outcomes of students of class VIII SMP N 15 Yogyakarta odd semester 2016/2017 academic year.

The summary of the results of the first hypothesis test can be seen in Table 4 .

Table 5.Summary of Second Hypothesis Test Results

\begin{tabular}{|c|c|c|c|}
\hline $\boldsymbol{t}_{\text {count }}$ & $\boldsymbol{t}_{\text {table }}$ & $\mathbf{d f}$ & Info \\
\hline 2,4354 & 2,0395 & 32 & $\begin{array}{l}\mathrm{H}_{0} \text { is rejected, } \\
\mathrm{H}_{1} \text { is accepted }\end{array}$ \\
\hline
\end{tabular}

From the second hypothesis test at a significant level of $5 \%$ and $\mathrm{dk}=32$, it can be seen that $t_{\text {count }}=$ 2,4354 and $t_{\text {table }}=2,0369$ so that $t_{\text {count }}>t_{\text {table }}$ This means there is a positive and significant relationship between parenting parents with mathematics learning outcomes for students of class VIII SMP N 15 Yogyakarta odd semester 2016/2017 academic year.

The summary of the results of the third hypothesis test can be seen in Table 6 . 
Table 6. Summary of Third Hypothesis Test Results

\begin{tabular}{|c|c|c|c|}
\hline $\boldsymbol{t}_{\text {count }}$ & $\boldsymbol{t}_{\text {table }}$ & $\mathbf{d f}$ & Info \\
\hline 3,5356 & 2,0395 & 32 & $\begin{array}{l}\mathrm{H}_{0} \text { is rejected, } \\
\mathrm{H}_{1} \text { is accepted }\end{array}$ \\
\hline
\end{tabular}

From the third hypothesis test at a significant level of $5 \%$ and $\mathrm{df}=32$, it can be seen that $\mathrm{t}_{\text {count }}=$ 3.5356 and $t_{\text {table }}=2.0369$ so $t_{\text {count }}>t_{\text {table }}$ which means there is a positive and significant relationship between the learning environment at school with student mathematics learning outcomes class VIII SMP N 15 Yogyakarta odd semester 2016/2017 school year.

The summary of the results of the fourth hypothesis test can be seen in Table 7 .

Table 7. Summary of Fourth Hypothesis Test Results

\begin{tabular}{|c|c|c|c|}
\hline $\boldsymbol{F}_{\text {count }}$ & $\boldsymbol{F}_{\text {table }}$ & $\mathbf{d k}$ & Info \\
\hline 4,2191 & \multirow{2}{*}{3,3048} & $\begin{array}{c}\mathrm{v}_{1}=2 \\
\mathrm{v}_{2}=31\end{array}$ & $\begin{array}{c}\mathrm{H}_{0} \text { is rejected, } \\
\mathrm{H}_{1} \text { is accepted }\end{array}$ \\
\hline
\end{tabular}

From the fourth hypothesis test at a significant level of 5\%, the numerator $\mathrm{v}_{1}=2$ and the denominator $\mathrm{v}_{2}=31$ so that it can be obtained $F_{\text {count }}=4,2191$ and $F_{\text {table }}=3,3048$ so that $F_{\text {count }}>F_{\text {table }}$ This means there is a positive and significant relationship between learning independence and parenting parents with mathematics learning outcomes of students of class VIII SMP N 15 Yogyakarta odd semester 2016/2017 school year.

The summary of the results of the fifth hypothesis test can be seen in Table 8 .

Table 8. Summary of the Fifth Hypothesis Test Results

\begin{tabular}{|c|c|c|c|}
\hline $\boldsymbol{F}_{\text {count }}$ & $\boldsymbol{F}_{\text {table }}$ & df & Info \\
\hline 6,3797 & \multirow{2}{*}{3,3048} & $\begin{array}{c}\mathrm{v}_{1}=2 \\
\mathrm{v}_{2}=31\end{array}$ & $\begin{array}{c}\mathrm{H}_{0} \text { is rejected, } \\
\mathrm{H}_{1} \text { is accepted }\end{array}$ \\
\hline
\end{tabular}

From the fifth hypothesis test at a significant level of $5 \%$, the numerator $\mathrm{v}_{1}=2$ and the denominator $\mathrm{v}_{2}=31$ so that it can be obtained $F_{\text {count }}=6,3797$ and $F_{\text {table }}=3,3048$ so that $F_{\text {count }}>F_{\text {table }}$ This means that there is a positive and significant relationship between learning independence and the learning environment at school with mathematics learning outcomes for students of class VIII SMP N 15 Yogyakarta odd semester 2016/2017 academic year.

The summary of the results of the sixth hypothesis test can be seen in Table 9.

Table 9. Summary of the Results of the Sixth Hypothesis Test

\begin{tabular}{|c|c|c|c|}
\hline $\boldsymbol{F}_{\text {count }}$ & $\boldsymbol{F}_{\text {table }}$ & $\mathbf{d k}$ & \multicolumn{1}{c|}{ Info } \\
\hline 9,3400 & 3,3048 & $\begin{array}{l}\mathrm{v}_{1}=2 \\
\mathrm{v}_{2}=31\end{array}$ & $\begin{array}{l}\mathrm{H}_{0} \text { is rejected, } \\
\mathrm{H}_{1} \text { is accepted }\end{array}$ \\
\hline
\end{tabular}

From the sixth hypothesis test at a significant level of 5\%, the numerator $\mathrm{v}_{1}=2$ and the denominator $\mathrm{v}_{2}=31$ so that it can be obtained $F_{\text {count }}=9,3400$ and $F_{\text {table }}=3,3048$ so that $F_{\text {count }}>$ $F_{\text {table }}$ This means that there is a positive and significant relationship between parenting parents and the learning environment at school with mathematics learning outcomes for students of class VIII SMP N 15 Yogyakarta odd semester 2016/2017 academic year.

The summary of the results of the seventh hypothesis test can be seen in Table 10.

Table 10. Summary of Seventh Hypothesis Test Results

\begin{tabular}{|c|c|c|c|}
\hline $\boldsymbol{F}_{\text {count }}$ & $\boldsymbol{F}_{\text {table }}$ & df & ket \\
\hline 451,4123 & 2,9223 & $\mathrm{v}_{1}=2$ & $\mathrm{H}_{0}$ ditolak, \\
$\mathrm{v}_{2}=30$ & $\mathrm{H}_{1}$ diterima \\
\hline
\end{tabular}

From the seventh hypothesis test at a significant level of 5\%, the numerator $\mathrm{v}_{1}=2$ and the denominator $\mathrm{v}_{2}=30$ so that it can be obtained $F_{\text {count }}=451,4123$ and $F_{\text {table }}=2,9223$ so that $F_{\text {count }}>$ 
$F_{\text {table }}$ This means there is a positive and significant relationship between learning independence, parenting parents and the learning environment at school with mathematics learning outcomes for students of class VIII SMP N 15 Yogyakarta odd semester 2016/2017 school year.

\section{CONCLUSION}

Based on the analysis of the experimental data and its discussion, this activity concludes several things as follows:

1. There is a positive and significant relationship between learning independence $\left(\mathrm{X}_{1}\right)$ and mathematics learning outcomes (Y) of eighth-grade students of SMP N 15 Yogyakarta odd semester 2016/2017 academic year. This is indicated by the t-test that is $t_{\text {count }}>t_{\text {table }}$ or2,4726 $>2,0369$. Simple correlation coefficient $(r)$ between learning independence with mathematics learning outcomes of 0.4005 and also obtained a coefficient of determination $\left(\mathrm{r}^{2}\right)$ of 0.1604 . And the simple regression equation $\mathrm{Y}$ for $\mathrm{X}_{1}$ is $\widehat{Y}=5,5703+0,6563 \mathrm{X}_{1}$.

2. There is a positive and significant relationship between parenting $\left(\mathrm{X}_{2}\right)$ and mathematics learning outcomes (Y) for students of class VIII SMP N 15 Yogyakarta odd semester 2016/2017 academic year. This is indicated by the t-test that is $t_{\text {count }}>t_{\text {table }}$ or $2,4354>2,0369$. Simple correlation coefficient ( $r$ ) between parenting parents with mathematics learning outcomes of 0.3945 and also obtained a coefficient of determination $\left(\mathrm{r}^{2}\right)$ of 0.1556 . In addition, we also obtain a simple regression equation for $\mathrm{Y}$ over $\mathrm{X}_{2} \widehat{\mathrm{Y}}=3,9314+0,6372 \mathrm{X}_{2}$.

3. There is a positive and significant relationship between the learning environment at school $\left(\mathrm{X}_{3}\right)$ and the mathematics learning outcomes (Y) of class VIII students of SMP N 15 Yogyakarta odd semester $2016 / 2017$ academic year. This is indicated by the t-test that is $t_{\text {count }}>t_{\text {table }}$ or $2,4726>$ 2,0369. Simple correlation coefficient ( $r$ ) between the learning environment in schools with mathematics learning outcomes of 0.5300 and also obtained a coefficient of determination $\left(\mathrm{r}^{2}\right)$ of 0.2809 . In addition, we also obtain a simple regression equation for $\mathrm{Y}$ over $\mathrm{X}_{3}$ is $\widehat{Y}=3,1780+$ $0,6735 \mathrm{X}_{3}$.

4. There is a positive and significant relationship between learning independence $\left(\mathrm{X}_{1}\right)$ and parenting $\left(\mathrm{X}_{2}\right)$ with mathematics learning outcomes (Y) in class VIII students of SMP N 15 Yogyakarta odd semester 2016/2017 academic year. This is indicated by the $F$ test that is $F_{\text {count }}>F_{\text {table }}$ or $4,2191>3,3048$. The multiple correlation coefficient (r) between learning independence and parenting parents with mathematics learning outcomes of 0.4626 and the coefficient of determination $\left(\mathrm{r}^{2}\right)$ of 0.2140 with linear line equations $\widehat{Y}=-15,5710+0,4484 \mathrm{X}_{1}+0,4252 \mathrm{X}_{2}$. The relative contribution of $X_{1}$ is $51.2380 \%$ and $X_{2}$ is $48.7720 \%$ and the effective contribution of $X_{1}$ is $10,9607 \%$ and $\mathrm{X}_{2}$ is $10,4353 \%$.

5. There is a positive and significant relationship between learning independence $\left(\mathrm{X}_{1}\right)$ and learning environment at school $\left(\mathrm{X}_{3}\right)$ with mathematics learning outcomes $(\mathrm{Y})$ for students of class VIII at SMP N 15 Yogyakarta odd semester 2016/2017 academic year. This is indicated by the F test that is $F_{\text {count }}>F_{\text {table }}$ or 6.3797> 3.3048. The multiple correlation coefficient (r) between learning independence and the learning environment in schools with mathematics learning outcomes of 0.5400 and the coefficient of determination $\left(r^{2}\right)$ of 0.2915 with linear line equations $\widehat{Y}=-6,5506+0,2116 \mathrm{X}_{1}$ $+0,5751 \mathrm{X}_{3}$. The relative contribution of $\mathrm{X}_{1}$ was $17.7338 \%$ and $\mathrm{X}_{3}$ was $82.2662 \%$ and the effective contribution of $\mathrm{X}_{1}$ was $5.1708 \%$ and $\mathrm{X}_{3}$ was $23.9872 \%$.

6. There is a positive and significant relationship between parenting $\left(\mathrm{X}_{2}\right)$ and the learning environment at school $\left(\mathrm{X}_{3}\right)$ with mathematics learning outcomes (Y) for students of class VIII SMP N 15 Yogyakarta odd semester 2016/2017 academic year. This is indicated by the $\mathrm{F}$ test which is $F_{\text {stat }}>$ $F_{\text {table }}$ or $9.33400>3.3048$. The multiple correlation coefficient (r) between parenting parents and the learning environment in schools with mathematics learning outcomes of 0.6144 and the coefficient of determination $\left(r^{2}\right)$ of 0.3775 with linear line equations $\widehat{Y}=-37,7613+0,5081 \mathrm{X}_{2}+0,6062 \mathrm{X}_{3}$. The 
relative contribution of $\mathrm{X}_{2}$ was $33.0262 \%$ and $\mathrm{X}_{3}$ was $66.9738 \%$ and the effective contribution of $\mathrm{X}_{2}$ was $12.4676 \%$ and $\mathrm{X}_{3}$ was $25.2831 \%$.

7. There is a positive and significant relationship between learning independence, parenting parents and the learning environment at school with mathematics learning outcomes for students of class VIII SMP N 15 Yogyakarta odd semester 2016/2017 school year. This is indicated by the F test which is $F_{\text {stat }}>F_{\text {table }}$ or 451.4123> 2.9223. The correlation coefficient (r) between learning independence, parenting parents and the learning environment at school with mathematics learning outcomes of 0.9891 and the coefficient of determination $\left(\mathrm{r}^{2}\right)$ of 0.9783 with linear line equations $\widehat{Y}=$ $-190,9314+2,1190 X_{1}-0,7093 X_{2}+1,5212 X_{3}$. The relative contribution of $X_{1}$ is $39.0475 \%, X_{2}$ is $13.216 \%$ and $X_{3}$ is $47.8309 \%$ and the effective contribution $X_{1}$ is $38.2013 \%, X_{2}$ is $12.8372 \%$ and $\mathrm{X}_{3}$ is $46.7943 \%$.

\section{REFERENCES}

Desmita. 2009. Psikologi Perkembangan Peserta Didik. Bandung: Remaja Rosdakarya.

Djamarah, Syaiful Bahri. 2011. Psikologi Belajar. Jakarta : PT Rineka Cipta.

2014. Pola Asuh Orang Tua dan Komunikasi dalam Keluarga. Jakarta : Rineka

Cipta.

Purwanto, N. 2014. Psikologi Pendidikan. Bandung : PT Remaja Rosdakarya Offset.

Slameto. 2013. Belajar dan Faktor-Faktor yang Mempengaruhinya. Jakarta : PT Rineka Cipta. 